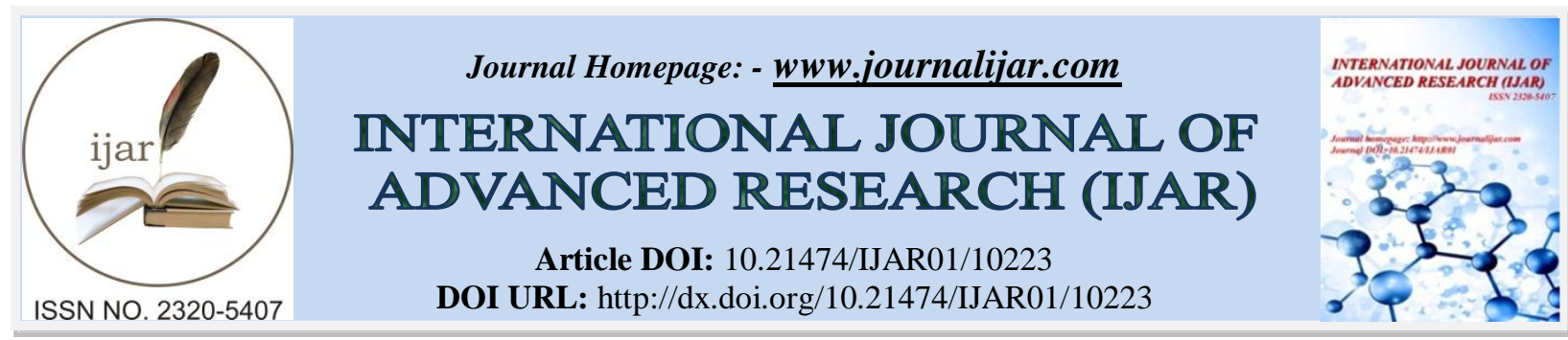

RESEARCH ARTICLE

\title{
STUDIES ON MICROBIAL PRODUCTION OF INDOLE ACETIC ACID FROM SOIL MICRO FLORA OF RAIGAD DISTRICT
}

\author{
Mr. S. N. Disale ${ }^{1}$, Dr. A. R. Kshirsagar ${ }^{2}$ and Dr. P. P. Dixit ${ }^{1}$
}

1. Department of Microbiology, Dr. B.A.M.University, Sub Campus, Osmanabad, Maharashtra, India.

2. Department of Microbiology, V.P. College, Patoda, Dist. Beed, Maharashtra, India.

\section{Manuscript Info}

Manuscript History

Received: 10 October 2019

Final Accepted: 12 November 2019

Published: December 2019

Key words:-

Indole Acetic Acid, Optimization, Rhizospheric Soil, Nitrogen

\begin{abstract}
Indole acetic acid (IAA) production is a major property of rhizosphere bacteria that stimulate and facilitate plant growth. The present work deals with isolation, characterization and identification of Indole acetic acid producing bacteria from the rhizospheric soil from Raigad district. Out of ten isolates four isolate were selected as efficient Indole acetic acid producers. Optimization of Indole acetic acid production was carried out at different cultural conditions of $\mathrm{pH}$ and temperature with varying media components such as carbon and nitrogen source, tryptophan concentration. Partial purification of IAA was done and purity was confirmed with thin layer chromatography. Subsequently, effect on plant growth was tested by measuring root and shoot length. In conclusion the study suggests the IAA producing bacteria can be used to promote plant growth.
\end{abstract}

Copy Right, IJAR, 2019,. All rights reserved.

\section{Introduction:-}

Phytohormones play an important role as signals and regulators of growth and development in plants. Auxins, among them in particular indole-3-acetic acid (IAA), are the most studied plant growth regulators, and this includes physiological, biochemical and genetic aspects. (Elena S. et al., 2002) [9]. Indole acetic acid (IAA) is one of the most physiologically active Auxins.

A large number of rhizobacteria produce Auxins, a plant growth hormone, which has a role in plant growth and development. Research has demonstrated that Auxins producing bacteria can be successfully used in increasing crop yield (Arshad M. et al. 1999) [2]. Auxins producing bacteria also have deleterious effects as well (Sarwar and Kremer 1995) [18]. Furthermore, little is known concerning the phylogenetic identities of auxin producing bacterial communities, or the distribution of auxin production levels among auxin producing bacteria. Tryptophan (TRP) is a major precursor for auxin production by many of rhizobacteria (Kamilova et al. 2006) [15], and may serve as a source of nitrogen for some bacteria, which may be the reason for the large increase in Indole-3- acetic acid (IAA) production in some bacteria challenged with TRP (Martens and Frankenberger, 1993) [19]. Pseudomonas spp., for example, increased auxin levels after being supplemented with TRP (Kravchenko et al. 2004) [16].

Auxin producing rhizobacteria have been studied extensively for decades. As far as we know, nobody has yet to isolate and characterize a large collection of culturable rhizobacteria from any plant species or from different cultivars and test them for the ability to produce auxin. Furthermore, no one has yet to functionally link auxin production from a wide range of auxin producers to biomass productivity. Therefore, the aims of this study were to India. 
connect the in vitro amounts of auxin produced by culturable rhizobacteria in the presence or absence of Ltryptophan and biomass productivity.

\section{Materials and Methods:- Collection of soil sample:}

The soil samples were collected from rhizosphere area of wheat, paddy field and coconut tree in polythene bag and brought to the laboratory. All soil samples were taken from $10 \mathrm{~cm}$ below the soil surface.

\section{Collection of soil sample:}

$5 \mathrm{gm}$ of each soil sample was inoculated in $100 \mathrm{ml}$ conical flask containing sterile nutrient broth supplemented with $0.1 \%$ tryptophan (Shahab et al, 2009) [20]. The flaks were labeled as, for wheat soil: WS, for paddy field soil: PS, for Coconut tree soil: CS.

The flasks were kept for enrichment by incubating at room temperature for $24 \mathrm{hrs} .0 .1 \mathrm{ml}$ of enriched sample was plated on nutrient agar plate and further incubated for $24 \mathrm{hrs}$ at room temperature.

\section{Screening of bacterial isolates for IAA production:}

10 isolated colonies were inoculated in sterile $10 \mathrm{ml}$ nutrient broth tubes supplemented with $01 \%$ tryptophan and incubated at room temperature for $24 \mathrm{hrs}$. IAA production was determined in vitro by the method of Salkowski (Shahab et al, 2009) [20]. From each of the tube, $1.5 \mathrm{ml}$ of culture was taken in centrifuge tube and centrifuged for $10 \mathrm{~min}$ at $7000 \mathrm{rpm}, 1 \mathrm{ml}$ of supernatant was taken and mixed with $3 \mathrm{ml}$ of Salkowski's reagent and incubated for 30 min. in dark for development of pink color. Spectrophotometric analysis of each sample was done for IAA detection. The isolate which showed higher absorbance at $520 \mathrm{~nm}$ were considered as efficient IAA producers and chosen for further experimental procedure.

\section{Preparation of standard graph:}

Different concentrations of IAA were prepared in nutrient broth ranging from 10 to $100 \mu \mathrm{g} / \mathrm{ml}$. $1 \mathrm{ml}$ of broth was mixed with $3 \mathrm{ml}$ of Salkowski's reagent and incubated at room temperature in dark for $30 \mathrm{~min}$. The absorbance of tube showing pink color was taken at $520 \mathrm{~nm}$ using spectrophotometry. Then, standard graphs were prepared by plotting concentration of IAA in $\mu \mathrm{g} / \mathrm{ml}$ optical density at $520 \mathrm{~nm}$.

\section{Morphological and Biochemical characterization:}

All the isolates were morphologically analyzed by measuring size, shape, and surface, color of colony, margin, elevation, opacity, consistency, motility and Gram staining.

\section{Indole Test:}

Peptone water was inoculated with test organism and incubated at $37^{\circ} \mathrm{C}$ for 24 to 48 hours. $5 \mathrm{ml}$ of KOVAC's reagent was added along the side of the test tube to form a layer on the top. A positive reaction was indicated by the formation of pink ring at the junction.

\section{Glucose Fermentation:}

Pure cultures were inoculated from the agar plates to sugar media and incubated at $37^{\circ} \mathrm{C}$ for $1-2$ days. Positive test was shown by acid and gas production by change in colour of the media (pink with indicator) and gas inside the Durham's tube.

\section{Citrate Utilization Test:}

Test organism was inoculated in Simmons citrate agar and incubated at $37^{\circ} \mathrm{C}$ for 2 days. Blue medium with a streak of growth was indicated in citrate utilizing bacteria (positive reaction).

\section{Methyl Red Test:}

Test organism was inoculated on glucose phosphate broth and incubated at 37 for 48 hrs. 5 to 6 drops of methyl red reagent was added to the culture. A red colour indicated positive reaction. Negative tests were yellow in colour. Positive reaction indicated the ability of the organism to produce and maintain an acid $\mathrm{pH}$. 


\section{Voges-Proskauer Test:}

The test organism was inoculated in glucose phosphate broth and incubated at 37 for 48 hours. Then VP reagent $(1 \mathrm{ml}$ of $40 \%$ potassium hydroxide $3 \mathrm{ml}$ of 5\% alpha napthol in absolute ethanol) was added. The tube was shaken vigorously to ensure maximum aeration. A positive result was indicated by the development of pink color in 2-5 minutes becoming crimson in 30 minute.

\section{Gelatinase test:}

The isolates were grown in sterile N.B. containing $12 \%$ gelatin and Incubated for 24 hrs. at room temperature. After $24 \mathrm{hrs}$, the incubated tubes were kept in freeze for $30 \mathrm{~min}$ and observed for liquification.

\section{Amylase test:}

Starch agar plates were prepared. The pure cultures of isolate were striked at the center of each plate and incubated at $37^{\circ} \mathrm{C}$ foe $24 \mathrm{hrs}$. After incubation iodine solution was flood over the plates. Observed for the blue color change around culture.

\section{Catalase Test:}

Pour 1-2 $\mathrm{ml}$ of hydrogen peroxide solution into a 4 test tube. Using a sterile wooden stick or a glass rod, take several colonies of the 18 to 24 hours old isolate and immerse in the hydrogen peroxide solution and observe for immediate bubbling.

\section{$\mathrm{H}_{2} \mathrm{~S}$ Production:}

4 SIM agar slant were prepared and each isolates was striked on the slant. The slants were incubated at $37^{\circ} \mathrm{C}$ for 24 hrs. The slants were observed for the occurrence of $\mathrm{H} 2 \mathrm{~S}$ production (black coloration) along the growth of culture.

2f) Effect of different factors on IAA production:

\section{Effect of Tryptophan concentration:}

4 sterile test tubes each containing $10 \mathrm{ml}$ nutrient broth was prepaid. The tubes were supplemented with varying concentration of tryptophan viz, $0.1 \%, 0.2 \%, 0.3 \%, 0.4 \%, 0.5 \%$, and $0.6 \%$ (4 tubes each with same tryptophan concentration). Then the tubes were inoculated with 4 isolates for different incubation periods i.e. 24,48 , and 72 hrs. Respectively and the tubes were assessed for IAA concentration by Salkowski's method after each $24 \mathrm{hrs}$.

\section{Effect of pH:}

$40 \mathrm{ml}$ of sterile (Nutrient broth $+0.1 \%$ tryptophan) was prepared and distributed in 4 sterile test tubes with pH 2, 4, 6 and 8 respectively. The tubes prepared according to respective $\mathrm{pH}$ were inoculated with isolates and labeled according to culture inoculated and kept for incubation at room temperature for 24,48 , and $72 \mathrm{hrs}$. All the incubated samples were assessed for measuring IAA concentration by Salkowski's method after each $24 \mathrm{hrs}$.

\section{Effect of Temperature:}

$40 \mathrm{ml}$ of sterile Nutrient broth $+0.1 \%$ tryptophan was prepared and distributed in 4 sterile test tubes. The test tubes were inoculated with each of 4 isolates and incubated at $4^{\circ} \mathrm{c}, 37^{\circ} \mathrm{c}, 45^{\circ} \mathrm{C}$ and room temperature for $24 \mathrm{hrs}$. After incubation the concentration of IAA was determined using Salkowski's method.

\section{Results and Discussion:-}

Isolation and screening of IAA producing bacteria:

After assessing by using Salkowski's reagent it was found that all 3 enriched soil samples showed formation of pink color with high intensity. 10 isolated colonies were selected from all the three flasks and further used for isolation of IAA. Out of 10 isolates 4 isolates [I1, I2, I3, I4] were found to be positive for 1AA production. Out of four isolate I4 followed by $\mathrm{I} 2$ shows maximum absorbance at $520 \mathrm{~nm}$.

\section{Preparation of Standard graph:}

100 microgram/ $\mathrm{ml}$ stock of IAA was prepared. And standard graph was prepared as shown in Table 1.Observation: (Stock 100ug/ml)

\begin{tabular}{|l|l|l|l|l|l|l|l|}
\hline $\begin{array}{l}\text { Sr. } \\
\text { No. }\end{array}$ & $\begin{array}{l}\text { Conc. } \\
(\boldsymbol{\mu g} / \mathbf{m l})\end{array}$ & Stock & D/W & $\begin{array}{l}\text { Salkowski's } \\
\text { Reagent })\end{array}$ & $\begin{array}{l}\text { Incubation } \\
\left(\mathbf{2 5} \mathbf{5}^{\circ} \mathbf{C}\right)\end{array}$ & $\begin{array}{l}\text { Optical Density at } \\
\mathbf{5 2 0 n m}\end{array}$ \\
\hline 1 & 10 & 0.1 & 0.9 & $2 \mathrm{ml}$ & $25 \mathrm{~min}$. & 0.090 & \\
\hline
\end{tabular}




\begin{tabular}{|l|l|l|l|l|l|l|}
\hline 2 & 20 & 0.2 & 0.8 & $2 \mathrm{ml}$ & $25 \mathrm{~min}$. & 0.112 \\
\hline 3 & 30 & 0.3 & 0.7 & $2 \mathrm{ml}$ & $25 \mathrm{~min}$. & 0.196 \\
\hline 4 & 40 & 0.4 & 0.6 & $2 \mathrm{ml}$ & $25 \mathrm{~min}$. & 0.225 \\
\hline 5 & 50 & 0.5 & 0.5 & $2 \mathrm{ml}$ & $25 \mathrm{~min}$. & 0.319 \\
\hline 6 & 60 & 0.6 & 0.4 & $2 \mathrm{ml}$ & $25 \mathrm{~min}$. & 0.382 \\
\hline 7 & 70 & 0.7 & 0.3 & $2 \mathrm{ml}$ & $25 \mathrm{~min}$. & 0.430 \\
\hline 8 & 80 & 0.8 & 0.2 & $2 \mathrm{ml}$ & $25 \mathrm{~min}$. & 0.514 \\
\hline 9 & 90 & 0.9 & 0.1 & $2 \mathrm{ml}$ & $25 \mathrm{~min}$. & 0.586 \\
\hline 10 & 100 & 1.0 & 0 & $2 \mathrm{ml}$ & $25 \mathrm{~min}$. & 0.647 \\
\hline 11 & Blank & 0 & 1 & $2 \mathrm{ml}$ & -- & -- \\
\hline
\end{tabular}

Graph 1:- Standard graph of IAA.

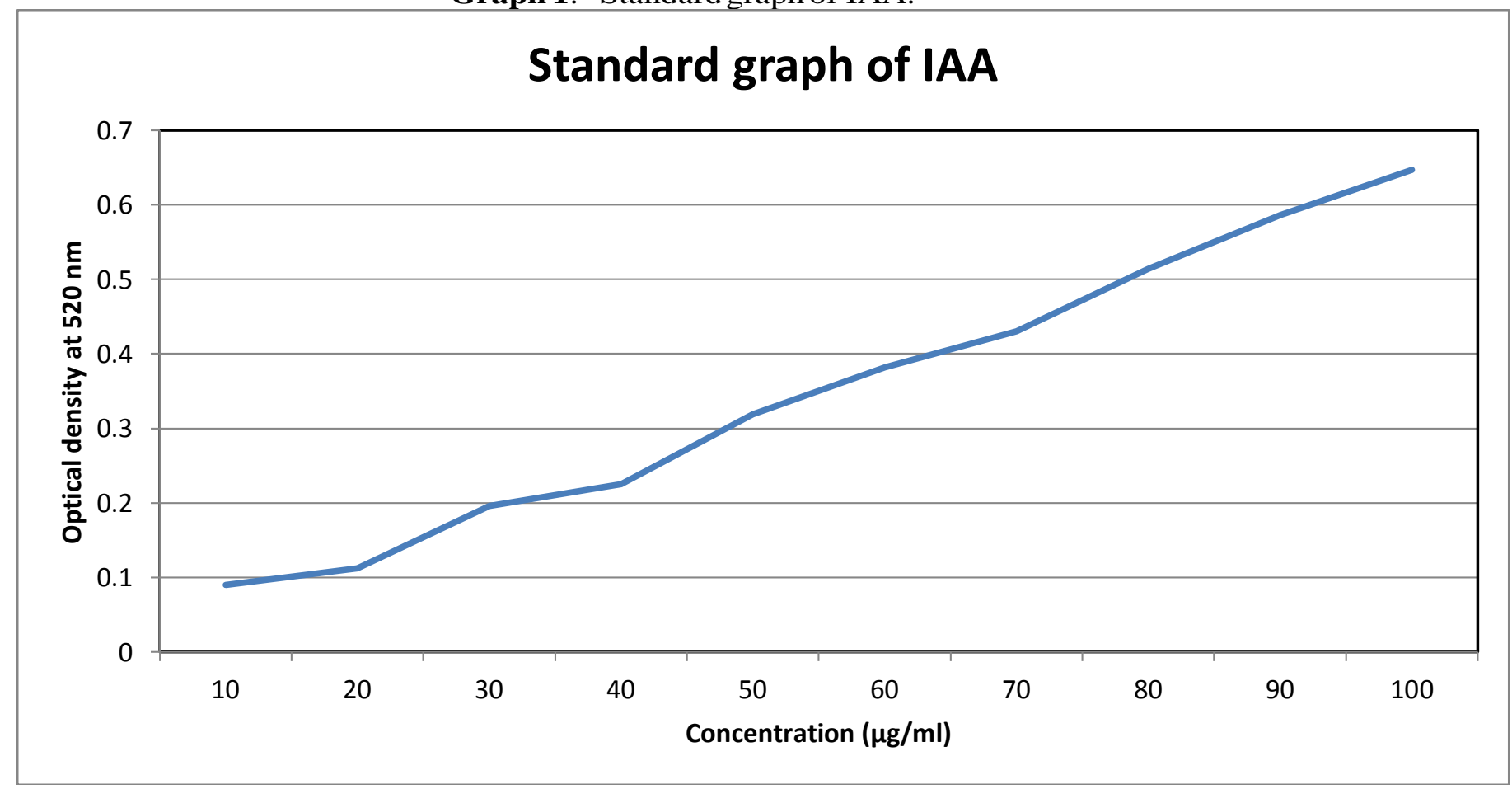

Morphological characters of the isolates:

Table 2:- After incubation of isolates on nutrient agar medium colony characteristics of each isolate were recorded and mentioned in Table 2.

\begin{tabular}{|l|l|l|l|l|l|}
\hline $\begin{array}{l}\text { Sr. } \\
\text { No. }\end{array}$ & Colony characters & I-1 & I-1 & I-1 & I-1 \\
\hline 1 & Size & $1.2 \mathrm{~mm}$ & $0.8 \mathrm{~mm}$ & $1.2 \mathrm{~mm}$ & $1.1 \mathrm{~mm}$ \\
\hline 2 & Shape & Circular & Circular & Circular & Circular \\
\hline 3 & Surface & Smooth & Smooth & Smooth & Smooth \\
\hline 4 & Color & White & White & White & White \\
\hline 5 & Margin & Entire & Entire & Entire & Entire \\
\hline 6 & Elevation & Convex & Convex & Convex & Convex \\
\hline 7 & Opacity & Opaque & Opaque & Opaque & Opaque \\
\hline 8 & Consistency & Butyrious & Butyrious & Butyrious & Butyrious \\
\hline 9 & Motility & Motile & Motile positive & $\begin{array}{l}\text { Motile } \\
\text { ram podsitive }\end{array}$ & $\begin{array}{l}\text { Motile } \\
\text { ram negative } \\
\text { rods }\end{array}$ \\
\hline 10 & Gram's nature & $\begin{array}{l}\text { Gram negative } \\
\text { rods }\end{array}$ & $\begin{array}{l}\text { Gram } \\
\text { rods }\end{array}$ & \\
\hline
\end{tabular}


Biochemical Characterization:

Table 3:- Results of biochemical characterization were recorded and mentioned in Table 3.

\begin{tabular}{|l|l|l|l|l|l|}
\hline $\begin{array}{l}\text { Sr. } \\
\text { No. }\end{array}$ & Biochemical Tests & I-1 & I-1 & I-1 & I-1 \\
\hline 1 & Indole Test & Negative & Negative & Negative & Negative \\
\hline 2 & Methyl red Test & Negative & Negative & Negative & Negative \\
\hline 3 & Vogus-Proskour Test & Negative & Negative & Negative & Negative \\
\hline 4 & Citrate Utilization Test & Positive & Positive & Positive & Positive \\
\hline 5 & H2S production Test & Negative & Positive & Negative & Negative \\
\hline 6 & Catalase Test & Positive & Positive & Positive & Positive \\
\hline 7 & Amylase Test & Negative & Negative & Positive & Positive \\
\hline 8 & Gelatinase Test & Positive & Positive & Positive & Positive \\
\hline 9 & Glucose Fermentation & Negative & Positive & Positive & Negative \\
\hline
\end{tabular}

Effect of Tryptophan on IAA production:

The samples inoculated with varying concentration of tryptophan viz, $0.1 \%, 0.2 \%, 0.3 \%, 0.4 \%, 0.5 \%$ and $0.6 \%$ in nutrient medium have shown gradual increase in production of IAA with the increase of tryptophan concentration. The samples were assessed by Salkowski's method. The isolate (I4) showed maximum IAA production at $0.6 \%$ concentration of tryptophan for $48 \mathrm{hrs}$. Incubation.

\section{Effect of pH on IAA production:}

Effect of $\mathrm{pH}$ of medium on IAA production was determined by using varying the initial $\mathrm{pH}$ medium viz, 2, 4, 6, and 8. Each tube was then inoculated with 4 isolates separately and incubated at room temperature for 24 hrs. The samples were assessed by Salkowski's method. I-1 and I-3 showed maximum IAA production at $\mathrm{pH} 2$, whereas optimum $\mathrm{pH}$ for I-2 and I-4 was 8.

\section{Effect of Temperature on IAA production:}

Effect of temperature of incubation on IAA production was determined by varying the temperature viz, $4^{\circ} \mathrm{C}, 37^{\circ} \mathrm{C}$, $45^{\circ} \mathrm{C}$ and room temperature. After incubation the samples were assessed by Salkowski's method. At room temperature I-1 and I-3 shows maximum production after $72 \mathrm{hrs}$. of incubation.

\section{Discussion:-}

Indole acetic acid (IAA) is a member of phytoharmones and considered as an active auxin. Total four isolates were identified as potential of IAA production. This type of studies has been conducted earlier for isolation of the IAA producing bacteria (Mohite et al. 2013) [4]. Earlier studies showed that IAA producing bacteria are gram negative bacteria (Datta et al. 2000) [7]. Few gram positive bacterial strains belonging to the Bacillus species are also kown for IAA producing capabilities (Wahyudi et al. 2011) [21]. Effect of different cultural conditions, growth stage and substrate availability (Mutluru et al. 2007) [22]

\section{Conclusion:-}

Soil is considered as the source of finding diverse kind of bacterial species. Soil samples are considered as priority for isolating IAA producing bacteria by considering ability of Raigad district soil consist of IAA producing bacteria. From this study, it is clear that rhizospheric soil can provide a rich source of IAA producing bacteria and has the ability to produce a significant amount of IAA in a tryptophan supplemented medium.

Overall four isolates were identified as IAA producing strains were characterized and media components, physical parameters were optimized for IAA production. These bacterial isolates were mainly Bacillus spp. and Pseudomonas spp.

\section{Acknowledgements:-}

The author wish to thank Department of Microbiology, Dr. B. A. M. U., Sub campus Osmanabad for allow to carrying out my research work. We are also grateful to staff member of Sub campus Osmanabad constant inspiration, motivation, and support for research work. 


\section{References:-}

1. Ali B, Sabri A. N., Ljung K. and Hasnain S 2009, Auxin Production by Plant Associated Bacteria: Impact on Endogenous IAA Content and Growth of Triticum aestivum L. Lett. Appl. Microbial. 48, 542-547.

2. Arshad M. and Frankenberger W T 1991 Microbial Production of Plant Hormones. Plant and Soil, 133, 1-8.

3. Arshad M., Frankenberger, W.T. Jr. 1992, Microbial production of plant growth regulators. In: Metting FB Jr (eds). Soil Microbial Ecol, Marcel Dekker Inc., New York. pp: 307-347.

4. B. Mohite 2013, Isolation and characterization of indole acetic acid (IAA) producing bacteria from rhizospheric soil and its effect on plant growth. Journal of Soil Science and Plant Nutrition 13(3), 638-649

5. Bianco C, Imperlini E, Calogero R, Senatore B, Amoresano A, Carpentieri A, Pucci P and Defez R 2006 Indole-3-acetic Acid Improves Escherichia coli's Defences to Stress. Arch. Microbial. 185, 373-382.

6. Carreno- Lopez, R., Campos-Reales, N.,Elmerich, C.and Baca, B.E. 2000, Physiological evidence for differently regulated tryptophan-dependent pathways for indole-3-acetic acid synthesis in Azospirillum brasilense. Mol. Gen. Genet. 264, 521- 530.

7. Datta, C., Basu, P. 2000. Indole acetic acid production by a Rhizobium species from root nodules ofaleguminous shrub Cajanus cojan. Microbial. Res. 155, 123-127.

8. Dickman MB, Mitra A. 1992. Arabidopsis thaliana as a model for studying Sclerotinia sclerotiorum pathogenesis. Physiol Mol Plant Pathol;41 :255-63

9. Elena Sergeeva, Anton Liaimer and Birgitta Bergman Planta 2002. Evidence for production of the phytohormone indole-3-acetic acid by cyanobacteria. Vol. 215, No. 2. pp. 229-238

10. Ellen Clark, Shula Manulis, Ykir Ophir, Isaac Barash and Yedidya 1993. Cloning and Characterization of iaaM and iaaH from Erwinia herbicola Pathovar gypsophilae Molecular Plant Pathology 83, 234-240.

11. Galdiano R F, Pedrinho E A N, Castellane T C L and Lemos E G D 2011. AuxinProducing Bacteria Isolated from the Roots of Cattleya wnlkeriana, and an endangered Brazilian Orchid, and Their Role in Acclimatization Rev. Bras. Cienc. Solo 35, 729-737.

12. Glickmann E, Gardan L, Jacquet S, Hussain S, Elasri M, Petit A and Dessaux Y 1998. Auxin Production is A Common Feature of Most Pathovars of Pseudomonas syringae. Mul. Plant-Microbe Interact. 11, 156-162.

13. Horemans, S., K. Vlassak, 1985. Production of indol- 3-acetic acid by Azospirillum brasilense. In: W. Klingmuller (Ed.), Azospirillum III: genetics, physiology, Ecol. Springer-Verlag, Berlin. Javt:u Manu Arshad M 1999 Potential of Plant Growth-promoting Rhizobactcria for Enhancing the Growth and Yield of Potato (Solanum tuberosum L.). Sarhad Journal of Agriculture 15 447-452.

14. Javed M and Arshad M 1999. Potential of Plant Growth-promoting Rhizobacteria for Enhancing the Growth and Yield of Potato (Solanum tuberosum L.). Sarhad Journal of Agriculture 15 447-452.

15. Kamilova F, Kravchenko L V, Shaposhnikov A I, Azarova T, Makarova N and Lugtenberg B 2006. Organic Acids, Sugars, and L-Tryptophan in Exudates of Vegetables Growing on Stonewool and Their Effects on Activities of Rhizosphere Bacteria MPMI 19, 250-256.

16. Kravchenko LV, Azarova T S, Makarova N M and Tikhonovich I A 2004. The Effect of Tryptophan Present in Plant Root Exudates on the Phytostimulating Activity of Rhizobacteria. Microbiology 73, 156-158.

17. Kuang-Ren, C., Turksen, S., Umran, E., Timmer, L. W., Peter, P.U. 2003. Indole derivatives produced by the fungus Colletotrichum acutatum causing lime anthracnose and postbloom fruit drop of citrus. FEMS Microbiology Letters. 226, 23- 30.

18. Sarwar M and Kremer R J 1995. Enhanced Suppression of Plant Growth through Production of L-tryptophan Derived Compounds by Deleterious Rhizobacteria. Plant and Soi1172, 261-269.

19. Martens D A and Frankenberger W T 1993. Metabolism of Tryptophan in Soil Soil Biol. Biochem. 25, 16791687.

20. Sadaf Shahab, Nuzhat Ahmed and Nasreen S. Khan 2009. Indole acetic acid production and enhanced plant growth promotion by indigenous PSBs. African journal of Agricultural research. 4(11):1312-1316.

21. Aris Tri Wahyudi, Rina Puji Astuti, Arsi Widyawati, Anja Meryandini and Abdjnd Asih Nawangsih, Characterization of Bacillus spp. Strains isolated from Rhizosphere of Soyabean plants for their use as potential plant growth for promoting Rhizobacteria, Journal of Microbiology and Antimicrobials Vol. 3, 2011, 34-40.

22. Mutluru Sridevi, Konada Veera Mallaiah, Bioproduction of Indole Acetic Acid by Rhizobium Strains Isolated from Root Nodules of Green Manure Crop, Sesbania sesban (L.) Merr., Iranian Journal of Biotechnology, Vol. 5, No. 3, July 2007, 178-182. 